\title{
REVITALISASI PERMAINAN TRADISIONAL BALI SEBAGAI BAGIAN DARI ATRAKSI WISATA BUDAYA DI KOTA DENPASAR
}

\author{
Putu Aditya Primayoga Arya \\ adityaprimayoga@gmail.com
}

\begin{abstract}
Recently, several traditional games suffer a setback as an impact of vast growing of modern, digital, and online games. This phenomenon raises a call to revitalise traditional games not only in order to strengthenen of folk cultures but also to promote them as tourist attractions. This article analyses attempts to revialise traditional games in the urban Denpasar, the capital city of Bali. The design of this study was descriptive qualitative by doing an observation, conducting a survey through spreading some questionnaires, depth interview and library research. The primary data sources were tradional games practioners, community leaders who have experiences and knowledge about Balinese traditional games as well as the heads of governmental sectors especially in the field of tourism and culture. The results of the study provides an overview of the following: there are external and internal factors why Balinese traditional games need to be revitalized. The external factor is connected with globalisation which has been bringing modern digital games. The internal factor comes from socio-cultural change, especially in the advanced development of civilization. Because of those factors, revitalization of Balinese traditional games is needed through cultural attraction festival which can attract local community and tourists to participate.
\end{abstract}

Keywords : Revitalisation, Traditional Games, Cultural Tourism, Cultural Attractions

\section{Pendahuluan}

Dalam dua dekade terakhir, Pemkot Denpasar mengembangkan diri sebagai Kota Berwawasan Budaya. Artinya, pemerintah memberikan perhatian yang besar hal-hal yang berkaitan dengan seni budaya melalui usaha pelestarian, revitalisasi, dan menjadikan nilai-nilai budaya sebagai dasar dan tujuan pembangunan. Hal ini terlihat dari pelaksanaan berbagai festival seperti Denpasar Festival, Sanur Village Festival, dan Pesona Pulau Serangan. Denpasar sejak tiga dekade terakhir menjadi venue untuk pelaksanaan 
tahunan Pesta Kesenian Bali yang dilaksanakan oleh Pemprov Bali sejak 1979. Dalam Pesta Kesenian Bali ini, pemerintah dan warga kota menunjukkan partisipasi aktif. Selain itu, dalam praktik pembangunan, Pemkot Denpasar juga mempromosikan nilai budaya sebagai way of life, misalnya dalam budaya birokrasi. Dulu pegawai negeri biasanya dikenal sebagai abdi negara yang tugasnya sepertinya melayani pejabat di atasnya, kini mereka menjadi abdi masyarakat, yakni melayani masyarakat. Dalam konteks perubahan ini, Pemkot Denpasar mengangkat selogan Sewaka Dharma, nilai budaya lokal yang berarti 'melayani sebagai kewajiban'. Artinya, pegawai negeri di Pemkot Denpasar wajib memberikan pelayanan kepada masyarakat untuk menyukseskan pembangunan, pemerataan, keadilan, dan juga kesejahteraan bersama.

Festival-festival yang digelar oleh Pemkot dijadikan arena untuk merevitalisasikan permainan tradisional, salah satu bentuk seni budaya yang terancam punah karena modernisasi dan globalisasi. Perkembangan permainan digital dan permainan on-line memikat banyak anak-anak, dan pada saat yang bersamaan dikhawatirkan menjauhkan mereka dari permainan tradisional yang dimainkan oleh nenek moyangnya. Made Taro (1999), tokoh yang gigih memperkenalkan permainan tradisional kepada anak-anak sekolah, mengatakan bahwa permainan tradisional merupakan kegiatan budaya tradisional dalam bentuk permainan dengan unsur-unsur gerak, seni sosial, dan budaya. Sebagai kegiatan budaya, permainan tradisional memperkuat nilai-nilai budaya yang dapat merangsang kreativitas (Foto 1).

Di Denpasar, ada 62 jenis permainan tradisional yang telah teridentifikasi. Salah satunya adalah Megoak-Goakan yang menggambarkan seekor gagak yang berusaha menangkap mangsanya. Permainan ini dimainkan oleh 10 anakanak dan para pemain yang bermain sebagai mangsa harus menghindari dan lari dari kejaran gagak. Namun, keberadaan Megoak-Goakan dan permainan tradisional Bali lainnya telah digantikan oleh permainan modern seperti video dan online games. Permainan modern yang berkembang saat ini memang sulit untuk dihindari. Untuk memainkannya, tidak membutuhkan area yang luas, tidak dibatasi oleh waktu, dan tidak perlu menunggu teman lain untuk ikut bermain. Eksistensi permainan modern tersebut mengakibatkan permainan tradisional menjadi jarang dimainkan dan ditampilan di kota Denpasar.

Untuk membuat permainan tradisional dapat berkelanjutan dan mempertahankan eksistensinya, maka perlindungan, pengembangan, dan pemanfaatan wajib dilakukan. Pemanfaatan mencakup beberapa upaya mengenalkan permainan tradisional sebagai atraksi budaya di kota Denpasar dalam berbagai kesempatan dengan tujuan untuk memperkuat citra identitas regional dan sebagai bagian pendidikan kesadaran budaya. Dengan demikian, pemanfaatan hasil melalui pengembangan pariwisata budaya merupakan salah satu langkah untuk menjaga budaya dan hasilnya bisa berkelanjutan (Edi Sedyawati, 2004: 76). 


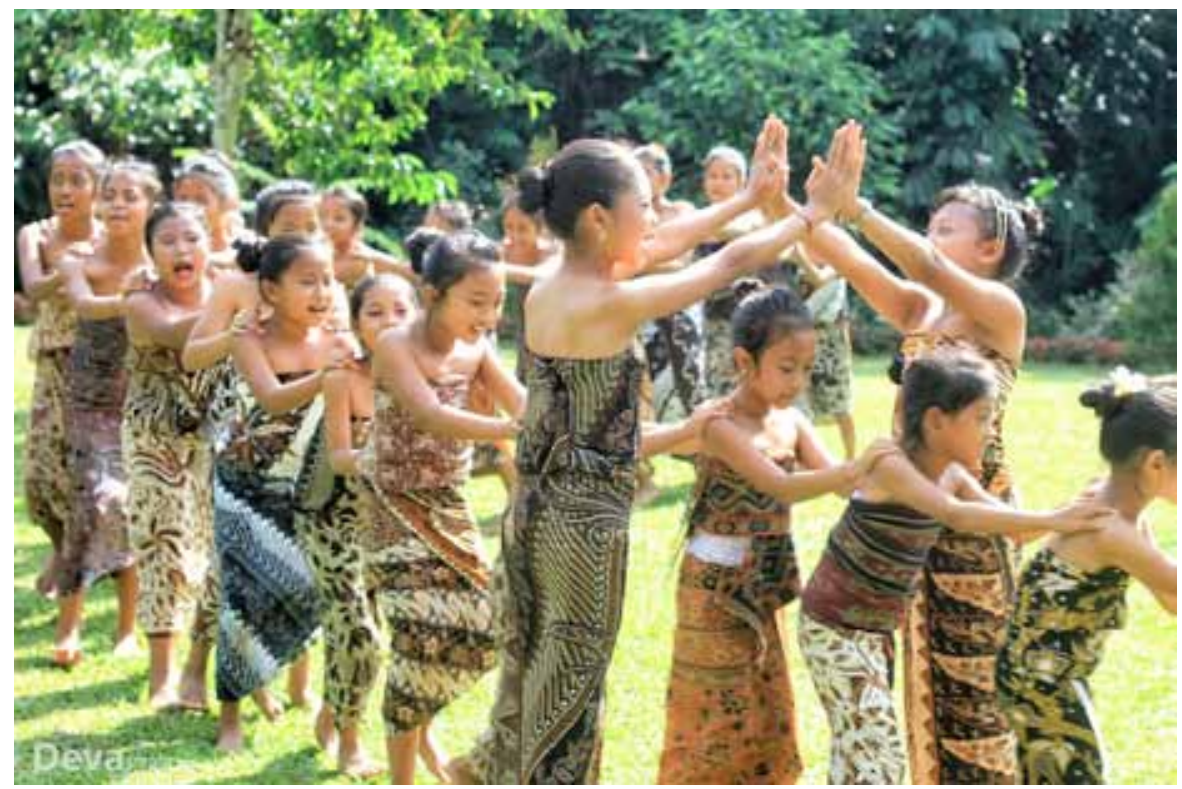

Foto 1. Permainan tradisional Bali bernama "Curik-curik" yang dimainkan anak-anak, difoto 7 April 2014 (Dokumentasi Pribadi Penulis).

Denpasar sebagai kota dengan beragam budaya harus terus menjaga eksistensi permainan tradisional dengan melakukan revitalisasi. Akan lebih baik untuk memperkenalkan dan melestarikan permainan tradisional kembali daerah masing-masing sebagai bagian dari hidup warisan budaya. Revitalisasi warisan budaya oleh Hamengkubowono X (2007) terinspirasi oleh beberapa motivasi, antara lain: (1) motivasi untuk melindungi warisan budaya dan sejarah, (2) motivasi untuk melestarikan keberadaan keragaman budaya yang kaya dengan karakteristiknya yang unik; (3) motivasi untuk menyegarkan identitas tertentu di antara kelompok-kelompok tertentu dalam masyarakat, (4) motivasi ekonomi untuk aspek-aspek tertentu dari nilai warisan budaya dan potensi untuk dikembangkan menjadi sumber pendapatan dari pariwisata. Selain itu, revitalisasi permainan tradisional adalah bagian dari hidup konservasi budaya. Konsep konservasi dibagi menjadi empat, yaitu: pelestarian, restorasi / rehabilitasi, rekonstruksi, dan revitalisasi (Puspasari, 1997: 196). Dalam melakukan revitalisasi permainan tradisional Bali, esensi dari budaya permainan tradisional tidak akan berubah terlalu banyak karena hanya memodifikasi "kemasan" yang diadaptasi berdasarkan perkembangan zaman di era modern ini.

\section{Metode Penelitian}

Penelitian ini dilakukan di kota Denpasar pada bulan Juni sampai dengan September 2013 dengan metode penelitian deskriptif-kualitatif. Penelitian 
ini berupaya memahami pentingnya revitalisasi permainan tradisional di kota Denpasar dengan tujuan untuk (1) mengidentifikasi faktor-faktor yang menyebabkan permainan tradisional perlu direvitalisasi, (2) memahami langkah-langkah dalam merevitalisasi permainan tradisional dan (3) mengetahui persepsi masyarakat setempat, seniman dan pemerintah tentang revitalisasi permainan tradisional Bali di kota Denpasar.

Adapun data yang digunakan di antaranya data primer yang diperoleh dari (1) kuesioner yang terdiri dari pertanyaan tertutup mengenai eksistensi, perkembangan dan potensi dari revitalisasi permainan tradisional Bali yang dibagikan kepada 150 responden di Kota Denpasar (2) in depth interview, di mana informan yang mempunyai pengalaman serta pengetahuan mengenai permainan tradisional diwawancarai dengan pertanyaan terbuka yang berkaitan dengan permainan tradisional Bali di kota Denpasar (3) check-list, dengan melakukan observasi terkait dengan potensi revitalisasi permainan tradisional dengan mengunjungi festival permainan tradisional yang diadakan di Museum Bali, PKB atau Studio Kukuryuk milik I Made Taro yang merupakan satu-satunya tempat di Denpasar yang mengajarkan permainan tradisional Bali. Data sekunder di dapat melalui dokumen-dokumen yang terkait dengan penelitian tersebut. Selanjutnya metode yang digunakan adalah pendekatan "multi-method" (Jonker and Pennink, 2010:92) yaitu mengkombinasikan antara kualitatif dan kuantitatif yang disajikan secara deskriptif.

\section{Faktor yang Mendorong Revitalisasi Permainan Tradisional Bali}

Permainan tradisional merupakan bagian integral dari kehidupan masyarakat Denpasar. Kata 'permainan' dalam Kamus Besar Bahasa Indonesia (2001: 697) berarti kegiatan yang bisa membuat seseorang bahagia dengan menggunakan atau bahkan tanpa peralatan apapun, misalnya, bermain sepak bola atau bermain drama dengan teman-teman. Permainan berfokus pada dua pesan utama yakni dari dua pesan utama: metacommuniccative message dan pernyataan realitas kontekstual.

Berbagai definisi permainan tradisional secara tidak langsung menyatakan bahwa permainan tradisional dapat dilakukan oleh semua orang dan tidak tergantung pada usia. Kegiatan ini telah dilakukan oleh orang-orang sedari anak-anak. Ada beberapa jenis permainan tradisional Bali yang dapat dimainkan oleh orang dewasa atau anak-anak hanya saja.

Taro (1999) menjelaskan ada lebih dari 150 jenis permainan tradisional di Denpasar. Karakteristik permainan tradisional di Denpasar adalah mudah untuk dimainkan, memiliki aturan dan lagu, tidak dibatasi oleh banyak peralatan, kaya variasi, kolektif dan fleksibel. Namun, keberadaan permainan tradisional Bali mulai mengalami penurunan di Denpasar. Pada tahun 1960-an dan 1970-an, sangat mudah untuk menjumpai masyarakat, baik tua maupun muda, yang bermain permainan tradisional seperti Megala-gala, Cingklak, 


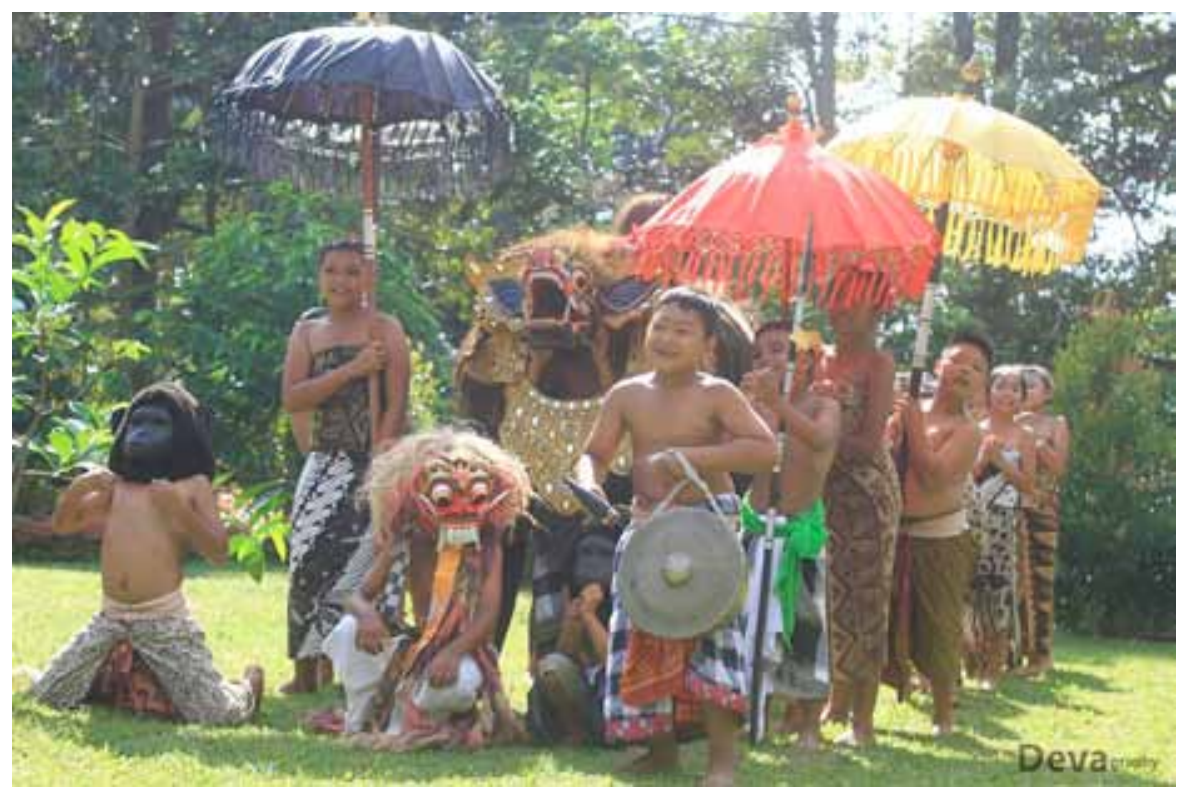

Foto 2. Permainan Tradisional Bali bernama "Mebarong" yang mengandung nilai-nilai Agama Hindu, diambil 7 April 2014 (Dokumentasi Penulis).

Tajog, Kasti, Megoak-goakan, dan Mebarong (Foto 2).

Selain eksistensi permainan modern yang merupakan bagian dari globalisasi, permasalahan lain yang menyebabkan ekesistensi permainan tradisional menjadi terganggu adalah perubahan sosial masyarakat Kota Denpasar sendiri. Ada teori yang memiliki perspektif yang menarik tentang perubahan sosial. Hal ini disebut teori siklus. Berdasarkan teori tersebut, diasumsikan bahwa perubahan sosial tidak dapat sepenuhnya dikendalikan oleh siapa pun, bahkan para ahli sekalipun. Dalam setiap masyarakat, ada siklus yang harus diikuti. Kebangkitan dan kejatuhan peradaban (budaya) tidak dapat dihindari dan perubahan sosial tidak selalu membawa efek yang baik. Zubaidi (1984) mengemukakan teori Oswald Spengler (1880-1936) yang menjelaskan bahwa setiap masyarakat berkembang melalui empat tahap perkembangan seperti pertumbuhan manusia, yaitu: masa kanak-kanak, remaja, dewasa, dan tua.

Arnold Toynbee menambahkan bahwa naik turunnya peradaban dapat dijelaskan melalui tantangan dan respon (konsep masyarakat) yang terkait satu sama lain. Ia telah mengamati bagaimana setiap masyarakat berusaha untuk menghadapi tantangan lingkungan alam dan sosial. Jika masyarakat mampu merespon dan beradaptasi dengan tantangan ini, maka masyarakat akan bertahan hidup dan berkembang. Sebaliknya, jika mereka tidak memiliki usaha apapun dan menyerah terhadap tantangan dan tanggapan, mereka akan menurun dan menghadapi kepunahan akhirnya. Menurut Toynbee 
(1976), jika tantangan dapat diatasi, tantangan baru akan muncul dan mereka harus dihadapi oleh masyarakat dalam bentuk interaksi timbal balik dengan lingkungan.

Ketika budaya mencapai puncak, maka keruntuhan (penurunan) mulai muncul. Keruntuhan terjadi dalam periode tiga yaitu: (1) Rincian peradaban terjadi karena hilangnya daya kreasi dan wewenangm oleh minoritas, maka mayoritas tidak akan lagi bersedia mengikuti minoritas. Peraturan dalam budaya (antara minoritas dan mayoritas pecah dan menghilang pasti; (2) Disintegrasi peradaban mulai muncul setelah budaya terhenti. Setelah berhenti, budaya akan membeku dan tidak memiliki jiwa lagi. Toynbee menyebut masa ini sebagai budaya fosil; (3) Pembubaran peradaban terjadi ketika budaya hancur dan menghilang.

Saat ini, perubahan mungkin terjadi sebagai hasil dari upaya para pemangku kepentingan untuk merevitalisasi dan meregenerasi permainan tradisional. Hal ini dapat dilakukan karena para pemangku kepentingan menyadari pentingnya permainan tradisional sebagai identitas budaya. Oleh karena itu, permainan tradisional akan tampil dalam berbagai bentuk modifikasi dan inovasi tanpa kehilangan esensi mereka.

Ketika ditanyakan tentang peran pemerintah untuk melestarikan permainan tradisional Bali, Made Taro menyatakan pemerintah telah berusaha untuk merevitalisasi permainan tradisional dengan menggelar beberapa kompetisi dan lokakarya. Bahkan, pemerintah telah menyelenggrakan sebuah acara bernama HOmPimPa (Kompetisi Permainan Tradisional) dan lokakarya tentang permainan tradisional Bali. Namun, masih terdapat cukup banyak masyarakat, khususnya masyarakat kota Denpasar, yang tidak tahu tentang kompetisi dan workshop tersebut. I Ketut Gde Suaryadala, Kepala Seksi Seni di Dinas Kebudayaan Kota Denpasar, dalam suatu wawancara menegaskan promosi tentang permainan tradisional telah dilakukan langsung ke studio seni dan sekolah. Di masa depan, ia percaya pemerintah akan mempromosikan permainan tradisional Bali melalui media dan pemerintah akan menyelenggrakana festival permainan tradisional di daerah terbuka seperti Alun-Alun dan Lapangan Puputan Renon bekerja sama dengan masyarakat kota Denpasar.

\section{Analisis SWOT Revitalisasi Permainan Tradisional sebagai Atraksi Wisata Budaya}

Analisis SWOT adalah instrumen yang digunakan untuk melakukan analisis strategis. Menurut Simbolon (1999), analisis SWOT merupakan cara yang efektif dalam penataan masalah, terutama dengan melakukan analisis terhadap faktor strategis, yang sering disebut sebagai faktor internal dan eksternal. Dalam faktor internal dan eksternal, pada dasarnya, ada empat unsur yang selalu dimiliki dan ditangani. Faktor internal memiliki sejumlah kekuatan dan kelemahan, dan faktor eksternal akan berhadapan dengan 
berbagai peluang dan ancaman. Analisis yang tepat untuk mengelola strategi disebut analisis SWOT.

Kegiatan yang paling penting dalam proses analisis SWOT adalah untuk memahami semua informasi dalam kasus, menganalisis situasi untuk menentukan masalah apa yang terjadi dan memutuskan tindakan apa yang harus dilakukan untuk memecahkan masalah (Rangkuti, 2001: 14). Pendekatan SWOT digunakan sebagai metode dalam penelitian ini karena memiliki banyak keuntungan dibandingkan pendekatan lain. Dengan analisis SWOT, situasi dan kondisi situasi permainan tradisional Bali bisa diketahui dengan mengidentifikasi faktor-faktor eksternal dan faktor internal tidak hanya melalui analisis peluang dan menentukan kekuatan rencana masa depan, tetapi juga mengatasi kelemahan dan ancaman dengan cara rencana perbaikan. Analisis ini didasarkan pada logika yang dapat memaksimalkan kekuatan dan peluang, dan pada saat yang sama dapat meminimalkan kelemahan, dan ancaman. Proses pengambilan keputusan strategis selalu berkaitan dengan pengembangan misi, tujuan, strategi, dan kebijakan yang ingin dicapai.

Berikut adalah analisis SWOT permainan tradisional Bali sebagai daya tarik wisata budaya:

Kekuatan

a) Terdapat banyak permainan tradisional Bali yang edukatif dan mengandung nilai kearifan lokal

b) Permainan tradisional Bali sangat fleksibel dan tidak mengandung unsur sacral

c) Permainan tradisional Bali merupakan bagian dari atraksi budaya yang pernah dipentaskan di festival besar seperti Pesta Kesenian Bali

Kelemahan

a) Hanya ada segelintir seniman yang merevitalisasi, mengenalkan, dan mengajarkan permainan tradisional Bali

b) Kurang dikembangkannya permainan tradisional Bali sebagai sebuah atraksi wisata budaya di kota Denpasar

c) Promosi pemerintah yang tidak ditujukan ke seluruh lapisan masyarakat Peluang

a) Ada banyak festival dan lokakarya mengenai permainan tradisional Bali

b) Ada seorang seniman bernama I Made Taro yang tekun melestarikan permainan tradisional kepada generasi muda

Ancaman

a) Dominasi permainan modern

b) Kepopuleran kesenian tradisional lain yang memiliki nilai jual seperti tarian dan music tradisional.

Strategi S-O

a) Mengadakan festival khusus permainan tradisional 


\section{Strategi W-O}

a) Promosi yang lebih luas kepada masyarakat kota Denpasar dan wisatawan

b) Modikasi untuk Komodifikasi Permainan Tradisional Bali dengan mengikuti kaidah yang berlaku

\section{Pendapat Praktisi Permainan Tradisional Bali}

Hasil wawancara dengan tokoh dan praktisi permainan tradisional Bali menunjukkan bahwa permainan rakyat ini sangat potensial untuk dikembangkan. Mereka optimistis terhadap tercapainya usaha-usaha pelestarian permainan tradisional di tengah kuatnya pengaruh permainan modern jika berbagai pihak termasuk pemerintah dan masyarakat mau melaksanakan pembinaan lewat berbagai hal termasuk pelaksanaan festival.

Praktisi permainan tradisional, I Made Taro, misalnya, menyampaikan bahwa ia sangat mendukung permainan tradisional Bali sebagai atraksi wisata budaya di Denpasar. Dengan digelarnya festival permainan tradisional, maka akan membuka kembali wawasan serta memberikan pengetahuan tidak hanya untuk masyarakat lokal tapi juga wisatawan tentang permainan tradisional yang ada di Bali yang layak untuk dilestarikan dan dikembangkan. Hal ini juga berfungsi sebagai media promosi wisata budaya di Denpasar.

Selain itu, ia juga mengharapkan festival atau acara dapat berkelanjutan dan diadakan secara rutin sebagai festival budaya lainnya. Hasil wawancara tersebut, dapat dikaitkan dengan teori persepsi (Rangkuti, 2002) yang meliputi faktor struktural dan personal. Faktor-faktor personal yang meliputi proses belajar, motif dan kebutuhan menggambarkan bahwa pendapatnya bersumber dari pengalamannya sebagai seorang seniman yang telah melestarikan permainan tradisional Bali melalui studio Kukuruyuk yang beliau dirikan sejak tahun 1970-an. Beliau bahkan sering memodifikasi permainan dalam upaya agar permainan tradisional Bali untuk tetap eksis di era modern.

Meskipun mereka dimodifikasi, Made Taro tidak pernah mengubah makna dan inti dari permainan tradisional tersebut. Di sisi lain, faktor-faktor struktural dapat mempengaruhi perencanaan acara permainan tradisional atau festival di masa depan dalam rangka untuk membuatnya lebih hidup dan mampu mengundang wisatawan lokal dan internasional. Bagi masyarakat lokal, pelestarian permainan tradisional melalui pariwisata akan membuat mereka berpartisipasi yang dapat membawa aspek positif untuk ekonomi mereka serta menumbuhkan kecintaan mereka terhadap permainan tradisional.

Dari wawancara dengan Nyoman Arka, salah satu guru besar di Universitas Udayana yang menulis sebuah buku berjudul Nilai Karakter Bangsa dalam Permainan Tradisional Anak-Anak Bali (2011), dapat dikatakan permainan tradisional Bali sebagai daya tarik wisata budaya adalah sebuah inovasi 
yang dapat meningkatkan jumlah wisatawan lokal dan internasional untuk mengunjungi Denpasar. Jika dilihat melalui faktor personal dalam teori persepsi, menurutnya, permainan tradisional Bali sering diabaikan karena tidak relevan dengan perkembangan zaman saat ini. Beliau menginginkan pelestarian permainan tradisional melalui atraksi budaya dapat dipertahankan dan tidak hanya sebagai ajang sesaat, berbasis proyek dan tanpa akar yang kuat di masyarakat. Secara singkat, dalam hal faktor struktural, permainan akan berkelanjutan jika ada motivasi yang kuat untuk berpartisipasi dalam konservasi mereka yang meliputi hal berikut. Pertama, motivasi untuk menjaga, memelihara dan menyampaikan warisan budaya yang diwariskan dari generasi sebelumnya; Kedua, Motivasi untuk meningkatkan pengetahuan dan cinta generasi penerus nilai-nilai sejarah identitas nasional dari waktu ke waktu melalui warisan kekayaan budaya dan nilai-nilai budaya yang secara signifikan dapat dilihat, diingat dan diinternalisasi; Ketiga, motivasi untuk menjamin keragaman budaya.

Di sisi lain, secara pribadi, Alit Sudibya, kepala bidang dokumentasi dan perfilman Dinas Kebudayaan Denpasar, mengatakan atraksi wisata budaya permainan tradisional, selain melestarikan permainan tradisional itu sendiri, juga akan menumbuhkan kesadaran masyarakat untuk memberikan pelatihan kepada generasi muda. Ada beberapa alasan mengapa pengembangan permainan tradisional sebagai salah satu atraksi wisata di Denpasar sangat diperlukan. Pertama, dari perspektif strategi kebudayaan, meningkatnya pengaruh globalisasi (permainan modern) telah mengurangi nilai-nilai budaya lokal (permainan tradisional). Sebenarnya, permainan tradisional memiliki potensi dan peran sebagai budaya tandingan (counter culture) untuk dominasi permainan modern yang dapat dianggap sebagai sesuatu yang tidak dapat dihindari (Fakih, 2003: 5).

Permainan tradisional memiliki nilai kearifan lokal sebagai salah satu sikap kritis untuk mencegah pengaruh yang massif dari permainan modern. Ini membuktikan dalam gaya hidup modern sebagai akibat dari globalisasi dan modernitas, masyarakat akan memiliki ketergantungan kuat pada agama, sastra dan seni. Munculnya tren baru gaya hidup yang berakar pada seni tradisional seperti permainan tradisional merupakan indikasi positif dari munculnya nilai-nilai lokal dalam kehidupan masyarakat. Selain itu, permainan tradisional yang dikemas baik dalam sebuah atraksi budaya maupun festival, bisa meningkatkan kreatifitas masyarakat dalam membuat berbagai atribut ekonomis penting yang terkait dengan permainan tradisional. Sebagaimana dinyatakan oleh Pendit (1999), industri pariwisata mampu meningkatkan pertumbuhan ekonomi dalam pekerjaan, pendapatan, standar hidup dan merangsang faktor produktivitas lainnya.

Menurut Suaryadala, kegiatan utama yang harus dilaksanakan adalah upaya pencitraan dari permainan tradisional Bali melalui perencanaan 
strategis, manajemen yang sistematis dan kemasan yang menarik (Adrienne L. Kaeppler di Falassi 1987:23) untuk disebarluaskan ke semua tingkatan masyarakat, baik nasional maupun internasional dalam upaya konservasi dan kebanggaan masyarakat akan permainan tradisional mereka sendiri. Hal ini dapat dilakukan dengan menyelenggarakan festival sebagai alat komunikasi yang penting untuk merevitalisasi dan memberdayakan permainan tradisional Bali. Upaya untuk melestarikan warisan budaya saat ini telah gencar dilakukan oleh banyak pihak. Ada banyak kuliner tradisional, festival seni, bangunan bersejarah atau berbagai kain tradisional diangkat menjadi identitas suatu daerah. Tapi di antara upaya ini, upaya untuk melestarikan permainan tradisional masih kurang. Festival permainan tradisional Bali masih jarang diadakan. Jika digelar sebagai acara budaya, festival permainan tradisional akan akan memiliki berbagai daya tarik karena membangkitkan nostalgia masa lalu. Di luar festival permainan tradisional, harus ada pendukung, peserta, dan pengunjung yang mempengaruhi proses pengelolaan festival permainan tradisional di Denpasar karena setiap festival budaya memiliki karakteristik sendiri untuk dapat menarik masyarakat lokal dan wisatawan. Selain itu, ada mata rantai yang hilang dalam warisan permainan tradisional Bali. Sebuah warisan, baik budaya, pengetahuan, atau bentuk-bentuk warisan lainnya akan dapat dipertahankan jika mereka diturunkan dari generasi ke generasi yang lebih muda. Ketika ada missing link dalam proses warisan, maka generasi yang lebih muda tidak mengenal permainan tradisional.

\section{Persepsi Masyarakat}

Persepsi masyarakat tenang revitalisasi permainan tradisional Bali sebagai atraksi wisata budaya di Denpasar dijaring melalui kuesioner. Penelitian dilakukan dari bulan Juni sampai Juli 2013 dengan menggunakan teknik pengumpulan data melalui kuesioner (random sampling) dan wawancara. Data yang telah berhasil diperoleh dari 150 responden memiliki karakteristik sebagai berikut; responden terdiri dari 29 laki-laki dan 27 perempuan dengan rentang usia 17-26 tahun responden, 21 laki-laki dan 27 wanita dalam rentang usia 27-36 tahun, 17 pria dan 13 wanita dalam kisaran 37-46 tahun dan 8 pria dan wanita dalam rentang usia 47-56 tahun. Semua responden berasal dan tinggal di Denpasar. Selain observasi langsung, data juga berasal dari wawancara mendalam dengan pertanyaan terbuka kepada lima orang ahli dengan tujuan untuk mengetahui dan mendapatkan data dari pengalaman, pendapat, perasaan, dan pengetahuan mereka tentang permainan tradisional Bali. Hasil wawancara telah direkam untuk menghindari manipulasi. Penulis menggunakan recall technique yang menggunakan pertanyaan yang sama tentang sesuatu untuk mendapatkan kepastian jawaban informan. Penyebaran kuesioner dengan 150 pertanyaan tertutup dibuat untuk orang-orang dari Denpasar yang terdiri dari berbagai kelompok, mulai dari pegawai negeri sipil, 
karyawan swasta, mahasiswa, dan pensiunan.

Analisis data menunjukkan bahwa $74 \%$ responden sangat setuju dan $21 \%$ responden setuju bahwa permainan modern telah membuat generasi muda tidak lagi mengenal permainan tradisional yang notabene juga warisan budaya bangsa dan hanya sebagian kecil yang kurang setuju responden (3\%) dan tidak setuju (2\%). Faktor lain adalah rasa kurangnya kebanggaan terhadap permainan tradisional. Meskipun 91\% responden menyatakan permainan tradisional adalah permainan yang diwariskan dari satu generasi ke generasi yang lain, bagaimanapun, masih ada $8 \%$ responden menyatakan bahwa permainan tradisional adalah permainan kuno.

Pelestarian permainan tradisional di Denpasar sebenarnya sudah dimulai digalakkan oleh pemerintah Kota Denpasar. Ada 58\% dari responden menyatakan setuju jika pemerintah telah melestarikan permainan tradisional Bali. Hal ini diperkuat oleh tingginya persentase responden (49\%) yang mengatakan mereka menyaksikan atraksi permainan tradisional tahun ketika penelitian ini dilakukan (2013). Namun, ada $15 \%$ responden yang menonton atraksi permainan tradisional dalam sepuluh tahun terakhir, bahkan $24 \%$ responden mengaku melihat pementasan permainan tradisional Bali lebih dari sepuluh tahun yang lalu. Tak bisa dipungkiri bahwa di era 70-90s, masyarakan akan sangat mudah untuk melihat anak-anak atau remaja bermain permainan tradisional. Pada 2013, pemerintah telah mulai meningkatkan permainan di festival game Bali Art Festival dan anak-anak di Museum Bali. Selain itu, ada juga festival anak tradisional game pada tahun 2011 yang terletak di Niti Mandala Renon yang diikuti oleh hampir semua kabupaten di Bali, kecuali Jembrana.

Di sisi lain, 27\% responden menyatakan kurang setuju jika pemerintah kota Denpasar sudah melestarikan permainan tradisional Bali dengan sangat baik. Hal ini disebabkan oleh promosi dari program pelestarian permainan tradisional di Denpasar tidak cukup besar dan menyeluruh ke semua lapisan masyarakat. Selain itu, jumlah festival permainan tradisional perlu ditingkatkan dan harus ada festival khusus permainan tradisional Bali. Karena fakta-fakta, pemerintah diharapkan untuk mengadakan festival lebih sering dengan promosi yang efektif untuk semua lapisan masyarakat.

Pelestarian paling dasar dari permainan tradisional Bali dapat dilakukan di TK, SD, SMP dan. Lima puluh sembilan persen responden sangat setuju dan tiga puluh delapan persen setuju para guru di sekolah mengajarkan permainan tradisional kepada anak didiknya dan tidak ada responden pun yang tidak setuju atau sangat tidak setuju dengan langkah ini. Proses pelestarian permainan seharusnya dimulai dari usia dini yang dikembangkan lebih lanjut dalam bentuk atraksi budaya. Diharapkan revitalisasi permainan tradisional melalui pendidikan di sekolah dapat terus membawa inovasi dan kreativitas guru dan pemain (Foto 3). Selain sekolah, juga bisa dilakukan oleh 
orang tua di rumah, guru di studio seni atau bermain bersama dengan temanteman. Meskipun permainan tradisional dapat direvitalisasi di tingkat sekolah yang terdiri dari anak-anak di bawah usia 13 tahun, tidak semua permainan tradisional bisa dimainkan oleh anak-anak. Ada beberapa permainan tradisional Bali yang dimainkan oleh orang dewasa.

Dari hasil kuesioner, ada 42\% responden tidak setuju bahwa permainan tradisional hanya dimainkan oleh anak-anak dan $28 \%$ responden sangat tidak setuju dengan pernyataan ini. Hampir semua permainan tradisional dapat dimodifikasi untuk dimainkan oleh orang-orang dalam berbagai kategori usia karena banyak permainan tradisional Bali yang sangat fleksibel. Permainan tradisional Goak-Goakan, misalnya, yang bisa dimainkan oleh orang-orang dalam berbagai kategori usia. Jika permainan yang dimainkan oleh orang dewasa, tingkat kesulitan dapat ditingkatkan. Selain itu, ada juga permainan lain yang disebut Gebug Ende permainan yang biasanya dimainkan oleh remaja dan orang dewasa karena permainan ini merupakan pertarungan satu lawan satu menggunakan rotan dengan para pemain hanya mengenakan sarung tradisional Bali yang disebut kamen (Foto 3). Jika pemain terkena pukulan dari rotan, maka tubuh pemain akan memar dan berdarah. Peraturan dan latar belakang dari semua permainan tradisional Bali harus diinformasikan kepada publik untuk membuat orang tahu mana permainan harus dimainkan oleh anak-anak atau orang dewasa, dengan demikian, mereka tidak akan raguragu untuk memainkannya. Kompetisi dapat diselenggarakan sebagai media dalam memperkenalkan kembali permainan tradisional kepada masyarakat serta membuat masyarakat Denpasar berpartisipasi, menonton atau menjadi sponsor.

Mayoritas responden (81\%) juga setuju bahwa kota Denpasar sudah memiliki infrastruktur yang lengkap untuk mengadakan festival permainan tradisional. Pengembangan sektor pariwisata di Denpasar telah mendorong pemerintah daerah untuk menyediakan infrastruktur yang lebih baik, pasokan air, listrik, telekomunikasi, transportasi umum dan fasilitas pendukung lainnya sebagai konsekuensi logis yang dapat memberikan kepuasan bagi wisatawan dan masyarakat lokal itu sendiri. Jika suatu daerah memutuskan untuk mengembangkan pariwisata, maka harus menyediakan atraksi wisata, terutama pementasan atau pertunjukkan budaya yang dikemas dan diatur sedemikian rupa.

Di lain sisi, pariwisata akan mendorong pemerintah untuk menyediakan aksesibilitas seperti membangun jalan yang layak untuk angkutan wisata, sementara fasilitas pendukung pariwisata seperti hotel, losmen, restoran juga harus disiapkan. Pembangunan infrastruktur dapat dilakukan secara mandiri atau mengundang pihak swasta lokal bahkan investor asing, terutama untuk pembangunan berskala besar seperti pembangunan Bandara Internasional, dan sebagainya. Peningkatan dan pengembangan infrastruktur pariwisata juga 


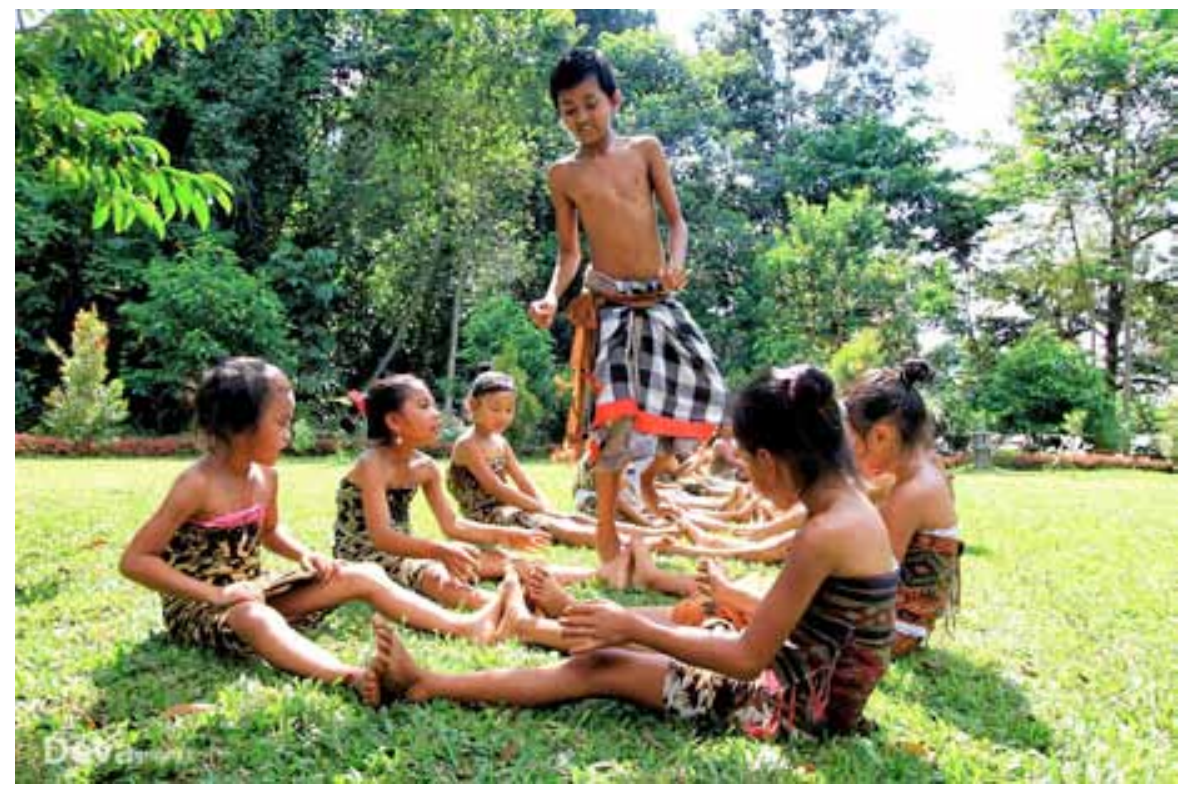

Foto 3. Anak-anak sekolah dalam permainan "Pandan-pandanan" yang dimodifikasi dan dipentaskan. Foto dijepret 7 April 2017 (Dokumentasi Penulis).

akan dinikmati oleh warga setempat dalam melaksanakan kegiatan usahanya, dalam konteks masyarakat setempat akan memiliki pengaruh positif terhadap perkembangan pariwisata.

Ketika responden diberikanpernyataanapakahpermainantradisional harus direvitalisasi melalui pariwisata dalam bentuk festival budaya, $71 \%$ responden mengatakan mereka setuju dan $24 \%$ mengatakan sangat setuju karena festival ini juga merupakan tempat bagi para seniman untuk mengekspresikan segala bentuk karya seni kreatif mereka. Dalam festival permainan tradisional, $68 \%$ responden setuju bahwa keterlibatan masyarakat lokal sangat penting karena merupakan kesempatan untuk mengarahkan semua potensi dan dinamika masyarakat dalam rangka untuk menyeimbangkan peran usaha pariwisata skala besar. Inijuga merupakan kunci untuk pengembangan festival permainan tradisional melalui keterampilan mereka seperti menyediakan berbagai kebutuhan wisatawan, baik untuk menyambut dan menginformasikan mereka tentang festival atau untuk membuat suvenir khas.

Mengenai waktu pelaksanaan, 57\% responden menyatakan setuju festival permainan tradisional digelar setahun sekali dalam skala besar sementara kompetisi dapat diadakan seminggu sekali. Ide untuk mengadakan kompetisi setiap akhir pekan dan festival setidaknya sekali setahun diperoleh melalui wawancara. Akhir pekan adalah waktu yang baik untuk melaksanakan kompetisi permainan tradisional karena orang biasanya akan melakukan rekreasi dengan keluarga atau teman. Untuk menarik perhatian mereka, 
kompetisi bisa digelar di ruang terbuka seperti di Niti Mandala Renon atau Puputan Badung. Diharapkan setelah wisatawan lokal dan internasional datang untuk melihat atraksi, jumlah mereka akan meningkat secara bertahap di masa depan. Ada 23\% responden kurang setuju kompetisi permainan tradisional yang diselenggarakan setiap akhir pekan dengan alasan itu akan membosankan jika diadakan terlalu sering. Namun, menurut hasil wawancara, hal itu bisa diatasi dengan melakukan berbagai permainan tradisional tarik masing-masing akhir pekan.

Hal yang mengejutkan adalah 53\% dari responden kurang setuju dengan modifikasi permainan tradisional sebagai bagian dari budaya Bali. Pementasan festival atau kompetisi permainan tradisional harus dilakukan dengan menggunakan pakaian tradisional Bali dan aksesoris yang berhubungan dengan budaya Bali. Modifikasi dapat dilakukan hanya melalui penambahan sound system atau pencahayaan. Di sisi lain $28 \%$ responden mendukung modifikasi atribut atau peralatan yang digunakan dalam permainan tradisional agar terlihat lebih menarik dan menghibur. Penggunaan bahasa juga dapat dikombinasikan (Bali, Bahasa Indonesia dan Bahasa Inggris) terutama untuk permainan tradisional yang dipentaskan dalam bentuk drama.

Mengadakan festival permainan tradisional tidak akan berhasil tanpa promosi. Hal ini dapat dilakukan melalui internet, brosur, media elektronik dan massa. Dari 150 responden, 54\% responden memilih Internet sebagai kampanye media yang kuat karena orang dapat mengaksesnya di mana saja dan kapan saja. Selain itu, biaya promosi melalui internet jauh lebih rendah daripada menggunakan media lain. Pemerintah dapat mempromosikan festival permainan tradisional melalui website resmi mereka. Selain itu, pemerintah juga dapat menggunakan situs jejaring sosial yang saat ini sedang menjadi tren di masyarakat. Di tempat kedua, ternyata brosur yang dipilih oleh $28 \%$ responden. Hal ini dianggap sebagai promosi yang efektif karena informasi memiliki informasi yang cukup jelas dan juga dapat ditanyakan lebih lanjut kepada orang-orang yang menyebarkan brosur. Penyebaran brosur sangat efektif jika dilakukan di tempat umum seperti mall, taman kota dan cafe. Di sisi lain, media elektronik dan massa mendapat kurangnya dukungan dari responden.

Di Kota Denpasar, ada banyak stasiun televisi dan radio, tetapi promosi melalui media elektronik tidak efektif karena selain dibatasi oleh durasi, informasi yang disampaikan sangat cepat dan tidak cukup jelas. Di sisi lain, melakukan promosi melalui media massa tidak efektif juga. Selain itu, promosi melalui media massa akan dengan mudah diabaikan dan cepat basi. Media pembaca koran atau majalah hanya membutuhkan waktu sekitar 15 menit sampai 30 menit untuk membacanya dan umumnya dan mereka hanya membaca sekali.

Ada beberapa kelompok tertentu yang tidak dapat dijangkau oleh surat 
kabar, kelompok tersebut dari orang di bawah 15 tahun. Meskipun ada sebuah surat kabar khusus untuk anak-anak dan remaja tetapi tidak dipublikasikan setiap hari dan mereka masih enggan untuk mengeluarkan uang untuk membelinya.

\section{Kesimpulan dan Saran}

Karena faktor globalisasi dan perubahan sosial budaya, revitalisasi permainan tradisional Bali diperlukan melalui atraksi festival budaya yang dapat menarik masyarakat setempat dan wisatawan yang akan berpartisipasi. Ini berarti permainan tradisional Bali menjadi komoditas turis. Komodifikasi permainan tradisional Bali bukan masalah karena merupakan bagian dari living culture yang bersifat hiburan. Permainan tradisional Bali yang tidak mengandung unsur-unsur sakral dan suci dapat dikomodifikasikan sebagai cara untuk menjaga eksistensi permainan tersebut.

Di Kota Denpasar, beberapa festival permainan tradisional Bali telah mulai digelar. Misalnya di Pesta Kesenian Bali yang terbukti mampu menarik masyarakat setempat dan wisatawan. Festival-festival budaya yang ada di Kota Denpasar seperti Denpasar Festival yang digelar setiap akhir tahun tidak hanya memberikan hiburan kepada masyarakat setempat dan wisatawan, tetapi juga menjadi momentum untuk memperkenalkan permainan tradisional Bali kepada generasi muda.

Melakukan regenerasi praktisi dianggap sebagai langkah pertama untuk merevitalisasi permainan tradisional Bali. Masalah regenerasi menjadi titik yang sangat penting untuk diperhatikan dalam rangka mempertahankan kelangsungan permainan tradisional di Denpasar. Diperlukan upaya dan perhatian dalam regenerasi seniman permainan tradisional Bali karena pengaruh kuat perubahan sosial di tingkat global dan sekolah adalah tempat yang tepat untuk melakukannya. Hal ini wajar karena generasi muda menghabiskan sebagian besar waktu mereka di sekolah. Hal ini dapat diterapkan dengan mengintegrasikan permainan tradisional Bali ke dalam muatan lokal.

Saat ini, kebanyakan orang tua memperkenalkan permainan modern untuk anak-anak mereka karena mereka sangat sibuk untuk mengajar permainan tradisional untuk anak-anak mereka, bahkan, mereka tidak tahu tentang permainan tradisional Bali. Orientasi ini harus diubah karena sangat penting untuk menumbuhkan rasa hormat generasi muda terhadap budaya Bali dengan cara menyelenggarakan festival permainan tradisional.

Meskipun beberapa festival sudah digelar, namun promosi yang lebih luas harus diterapkan. Hal ini dapat dilakukan melalui internet karena merupakan kampanye media yang kuat karena orang dapat mengaksesnya di mana saja dan kapan saja. Selain itu, biaya promosi melalui internet jauh lebih rendah daripada menggunakan media lain. Pemerintah dapat mempromosikan festival 
permainan tradisional melalui website resmi mereka. Selain itu, pemerintah juga dapat menggunakan situs jejaring sosial yang saat ini sedang booming di masyarakat. Penyebaran brosur juga dapat dipilih karena dianggap sebagai promosi yang efektif. Informasi ini cukup jelas dan juga dapat ditanyakan lebih lanjut kepada orang-orang yang menyebarkan brosur.

\section{Ucapan Terima Kasih}

Penulis menyampaikan ucapan terima kasih kepada Prof. Dr. dr. A. A. Raka Sudewi, Sp.S (K) selaku Direktur Program Pascasarjana Universitas Udayana. Madame Sylvine Chevalier Pickel sebagai penanggung jawab akademik program Double Degree Indonesia Prancis mahasiswa Universitas Udayana Bali di Université d'Angers, France. Prof. Dr. I Nyoman Sirtha, SH.,MS., sebagai pendahulu Ketua Program Studi Kajian Pariwisata Program Pascasarjana Universitas Udayana, dan Prof. Dr. I Nyoman Darma Putra sebagai Ketua Program Studi Kajian Pariwisata Program Pascasarjana Universitas Udayana saat ini. Apresiasi dan ucapan terima kasih juga penulis sampaikan kepada Bapak Nyoman Sunarta, M.Si sebagai Sekretaris Program Studi Kajian Pariwisata Program Pascasarjana Universitas Udayana terdahulu dan Dr. Ir. Syamsul Alam Paturusi, MSP sebagai Sekretaris Program Studi Kajian Pariwisata Program Pascasarjana Universitas Udayana saat ini. Prof. Made Sudiana Mahendra, Mapp.Sc.Ph.D. dan Prof. Dr. Ir. Made Antara,MS., sebagai dosen penguji yang telah memberikan banyak masukan, dan koreksi untuk menyempurnakan tesis ini.

Ucapan terima kasih juga didedikasikan kepada Pemerintah Indonesia dan Prancis yang telah merancang Program Double Degree dan segala bentuk dukungan selama proses pendidikan, khususnya bagi mahasiswa yang berminat melanjutkan studi tentang pariwisata di dua Negara. Keluarga, sahabat, dan seluruh pihak yang telah membantu dan memberi kepercayaan untuk menyelesaikan tesis ini tepat pada waktunya.

\section{Daftar Pustaka}

Ahmad, Zubaidi, 1984. Menelusuri Gagasan Filsafat Sejarah Oswald Spengler. Yogyakarta: Basis.

Departemen Pendidikan dan kubudayaan/Pusat Bahasa. 2001. Kamus Besar Bahasa Indonesia (Edisi ke-3). Jakarta: Balai Pustaka.

Fakih, Mansour, 2000. Runtuhnya Teori Pembangunan dan Globalisasi. Yogyakarta: Insist Press dan Pustaka Pelajar.

Jonker, Jan and Bartjan Pennink. 2010.”The Essence of Research Methodology, A Concise Guide for Master and PhD Student in Management Science”. SpringerVerlag, Berlin, Heidelberg, Germany.

Kaeppler, Adrienne L. 1987. "Pasific Festivals and Ethnic Identity". Dalam Alessandro Falassi (Ed.). Time Out of Time: Essays on the Festival (hlm.162-170). New 
Mexico: University of New Mexico Press.

Pendit, Nyoman S. 1999. Ilmu Pariwisata Sebuah Pengantar Perdana. Jakarta: PT. Pradnya Paramita.

Puspasari. 1997. "Penelitian Pengembangan Kesenian Tradisional”. Laporan Akhir. Jakarta: Proyek Penelitian dan Pengembangan Bidang Kebudayaan dan Pariwisata Kementrian Kebudayaan. Kementrian kebudayaan dan Pariwisata RI.

Rai, A.A. Gde (2003) Sustaining Culture through Tourism: Fact or Fluff (from heritage to legacy), The Pressentation in PATA Annual Conference, Bali.

Rangkuti, Freddy. 2002. Creating Effective Marketing Plan. Jakarta: PT. Gramedia Pustaka Utama.

Sedyawati, E. (1999). Permainan Anak-anak sebagai Aspek Budaya. Editor: Krisdyatmiko. Dolanan anak: Refleksi budaya dan wahana tumbuhkembang anak. Yogyakarta: Plan International Indonesia-Yogyakarta dan LPM Sosiatri Fisipol UGM.

Taro, Made. 1999. Bunga Rampai Permainan Tradisional Bali. Denpasar: Dinas Pendidikan Dasar Propinsi Bali.

Tonybee, Arnold. 1976. Sejarah Umat Manusia: Uraian Analitis, Kronologis dan Komparatif. Yogyakarta: Pustaka Pelajar Offset

\section{Biografi Penulis}

Putu Aditya Primayoga Arya, S.S. M.Par. adalah alumnus Magister Kajian Pariwisata, Double Degree Indonesia Prancis, dengan menempuh 1 tahun pendidikan Master di Universitas Udayana Denpasar kemudian melanjutkan 1 tahun berikutnya di Prancis tepatnya Université d'Angers, France jurusan Mention Management et Développement du Tourisme, de I'Hôtellerie, de la Restauration et des Loisirs. Ia menyelesaikan program studi Sarjana Strata I di Fakultas Sastra Universitas Udayana dengan mengambil jurusan Sastra Inggirs. Pengalaman yang dimiliki adalah pernah mengajar Bahasa Inggris di empat cabang Primagama di kota Denpasar, mengikuti berbagai event international seperti East Asian Summit, AVAR dan UNFCCC dan tenaga pengajar mata kuliah Bahasa Inggris di Fakultas Ekonomi, Universitas Mahasaraswati Denpasar sejak tahun 2011. Menterjemahkan artikel dari Bahasa Indonesia ke Bahasa Inggris dan dari Bahasa Inggris ke Indonesia adalah keahlian yang dimiliki. 